\section{A CHECKLIST OF BIRDS OF CALICUT UNIVERSITY CAMPUS, KERALA}

\author{
Muhamed Jafer Palot and P. Pramod \\ University of Calicut, Tenhipalam, Malappuram, Kerala 673635, \\ India
}

The University of Calicut campus is situated about $25 \mathrm{~km}$. from the historic city of Calicut $\left(11^{0} 25^{\prime} 45^{\prime \prime} \mathrm{N}\right.$ and $\left.75^{\circ} 45^{\prime} 50^{\prime \prime} \mathrm{E}\right)$ in Malappuram District of Kerala. The area is a flat topped laterite hillock, having a campus of about $25 \mathrm{sq} . \mathrm{km}$. The topography of the campus is comparatively plain supporting scrub jungles and cashew plantations in the slopes. The vegetation is dominated by the bushes of Calicopteris flouribunda, Lantana camara, Rauvolfia tetraphylla, Eupatorium odoratum, Clerodendrum infortunatum, etc, interspersed with tress like Mangifera indica, Macaranga peltata, Ficus benghalensis, Ficus religiosa, etc. The campus also has a very large Botanical Garden which attracts many birds.

During our stay, from 1993 to 1996, a total of 124 species of birds were recorded (See-List). Of these fourteen species are migrants, they are Kestrel, Indian Pitta, Short-toed Lark, Common Swallow, Brown Shrike, Golden Oriole, Paradise Flycatcher, Grey Drongo, Greenish Leaf Warbler, Blyths Reed Warbler, Richard's Pipit, Grey Wagtail, White Wagtail, Rose Finch. Some rare birds like the Stone Curlew, Brahminy Myna, Whitebrowed Fantail Flycatcher were breeding within the campus. Raptors such as, Blackwinged Kite, Honey Buzzard, Crested Hawk Eagle, Crested Serpent Eagle, Kestrel were occassionally sighted. Frugivorous birds like Grey-fronted Green Pigeon, Orange-breasted Green Pigeon, Common Green Pigeon, Lorikeet, Crimson-throated Barbet, Crimson-breasted Barbet, Blossom-headed Parakeet congregate on Ficus benghalensis tree during the fruiting season. Forest loving species like Chestnut-headed Bee-eater, Heartspotted Woodpecker, Fairy Blue Bird, Small Sunbird, Rose Finch were observed rarely in the campus.

Eventhough, the avifauna of the campus is rich, the bird habitat is threatened with the unplanned developmental activities like clearing of thickets, construction of buidings and cutting of large trees. In the recent past, the number of ground nesting species like Yellow-wattled Lapwing, Stone Curlew, Larks and Pipits have declined. Planting more indigenous fruiting trees and controlling cattle grazing may save this laterite bird habitat from destruction.

Received 2 July 1999;
Accepted 25 November 1999

\section{Acknowledgements}

We are thankful to Dr. D.N. Mathew and Dr. V.J. Zacharias of University of Calicut for the inspiration and support.

\section{References}

Ripley, S.D. (1982). A Synopsis of the Birds of India and Pakistan. Bombay Natural History Society. Bombay

\section{Checklist of birds of Calicut University campus*}

Family: Phalacrocoracidae

1. Little Cormorant

Phalacrocorax niger

Family : Ardeidae

2. Large Egret

3. Pond Heron

4. Cattle Egret

5. Smaller Egret

6. Little Egret

Ardea alba

Ardeola grayii

Bubulcus ibis

Egretta intermedia

E. garzetta.

Family : Accipitridae

7. Black-winged Kite

8. Honey Buzzard

9. Pariah Kite

10. Brahminy Kite

11. Shikra

12. Crested Hawk Eagle

13. Crested Serpent Eagle

Elanus caerulus

Pernis ptilorhyncus

Milvus migrans

Haliastur indus

Accipiter badius

Spizaetus cirrhatus

Spilornis cheela

Family : Falconidae

14. Kestrel

Falco tinnunculus

Family: Phasianidae

15. Jungle Bush Quail

Perdicula asiatica

Family : Burhinidae

16. Stone Curlew

Burhinus oedicnemus

Family: Charadriidae

17. Red-wattled Lapwing Vanellus Vanellus indicus

18. Yellow-wattled Lapwing

19. Little Ringed Plover

V. malabaricus

Charadrius dubius.

Family: Columbidae

20. Grey-fronted Green Pigeon

21. Orange-breasted Green Pigeon

Treron pompadoa

T. bicincta

22. Common Green Pigeon

23. Blue Rock Pigeon

24. Spotted Dove

25. Emerald Dove

T. Phoenicoptera

Columba livia

Streptopelia chinensis

Chalcophaps indica

Family: Psittacidae

26. Rose-ringed Parakeet

27. Blossom-headed Parakeet

28. Indian Lorikeet

Psittacula krameri

P. cyanocephala

Loriculus vernalis

Family : Cuculidae

29. Pied Crested Cuckoo

Clamator jacobinus

30. Common Hawk Cuckoo

Cuculus varius 
31. Indian Cuckoo

32. Koel

33. Crow-Pheasant

Family : Strigidae

34. Collared Scops Owl

35. Jungle Owlet

36. Brown Hawk-Owl

37. Spotted Owlet

38. Mottled Wood Owl

Family : Caprimulgidae

39. Common Indian Nightjar

Family : Apodidae

40. Indian Edible-Nest Swiftlet

41. House Swift

42. Palm Swift

Family : Alcedinidae

43. Lesser Pied Kingfisher

44. Stork-billed kingfisher

45. White-breasted Kingfisher

Family: Meropidae

46. Chestnut-headed Bee-eater

47. Blue-tailed Bee-eater

48. Small Green Bee-eater

Family : Coraciidae

49. Indian Roller

Family : Upupidae

50. Hoopoe

Family: Capitonidae

51. Small Green Barbet

52. Crimson-throated Barbet

53. Crimson-breasted Barbet

Family : Picidae

54. Lesser Golden-backed Woodpecker

55. Golden-backed Three-toed Woodpecker

56. Yellow-fronted Pied Woodpecker

57. Pigmy Woodpecker

58. Heart-spotted Woodpecker

Family: Pittidae

59. Indian Pitta

Family : Alaudidae

60. Bush Lark

61. Ashy-crowned Finch-Lark

62. Short-Toad Lark

63. Eastern Skylark

64. Malabar Crested Lark

Family: Hirundinidae

65. Common Swallow

66. Red-rumped Swallow

Family : Laniidae

67. Rufous-backed Shrike

68. Brown Shrike

Family : Oriolidae

69. Golden Oriole
C. micropterus

Eudynamys scolopacea

Centropus sinensis

Otus bakkamoena

Glaucidius radiatum

Ninox scutulata

Athene brama

Strix ocellata

Caprimulgus asiaticus

Collocalia unicolor

Apus affinis

Cypsiurus parvus

Ceryle rudis

Pelargopsis capensis

Halcyon smyrnensis

Merops leschenaulti

M. philippinus

M. orientalis

Coracias benghalensis

Upupa epops

Magalaima viridis

M. rubricapilla

M. haemacephala

Dinopium benghalense

D. javanense

Picoides mahrattensis

P. nanus

Hemicircus canente

Pitta brachyura

Mirafra assamica

Eremopterix grisea

Calandrella cinerea

Alauda gulgula

Galerida malabarica

Hirundo rustica

H. daurica.

Lanius schach

L. cristatus

Oriolus oriolus
70. Black-headed Oriole

O. xanthornus

Family : Dicruridae

71. Black Drongo

72. Ashy Drongo

73. Greater Racket-tailed Drongo

Family: Artamidae

74. Ashy Swallow-Shrike

Family : Sturnidae

75. Grey-headed Myna

76. White-headed Myna

77. Brahminy Myna

78. Common Myna

79. Jungle Myna

Family : Corvidae

80. Indian Tree Pie

81. House Crow

82. Jungle Crow

Family: Campephagidae

83. Malabar Wood Shrike

84. Large Cockoo-Shrike

85. Black-headed Cuckoo-Shrike

86. Scarlet Minivet

87. Small Minivet

Family: Irenidae

88. Common lora

89. Gold-fronted Chloropsis

90. Gold-mantled Chloropsis

91. Fairy Bluebird

Family : Pycnonotidae

92. Red-whiskered Bulbul

93. Red-vented Bulbul

Family : Muscicapidae

94. Jungle Babbler

95. White-headed Babbler

96. Brown Flycatcher

97. Paradise Flycatcher

98. White-browed Fantail Flycatcher

99. Streaked Fantail Warbler

100. Franklins Wren-Warbler

101. Ashy Wren-Warbler

102. Tailor Bird

103. Blyth's Reed Warbler

104. Dull Green Leaf Warbler

105. Magpie-Robin

106. Pied Bush Chat

107. Indian Robin

Family : Motacillidae

108. Richard's Pipit

richardi

109. Paddyfield Pipit

110. Grey Wagtail

111. White Wagtail

112. Large Pied Wagtail

Family : Dicaeidae

113. Tickell's Flowerpecker

114. Thick-billed Flowerpecker
Dicrurus adsimilis

D. leucophaeus

D. pradiseus

Artamus fuscus

Sturnus malabaricus

S. malabricus blythii

S. pagodarum

Acridotheris tristis

A. fuscus

Dendrocitta vagabunda

Corvus splendens

C. macrorhynchos

Tephrodornis virgatus

Coracina novaehollandiae

C. melanoptera

Pericrocotus flammeus

$P$. cinnamomeus

Aegithina tiphia

Chloropsis aurifrons

C. cochinchinensis

Irena puella

Pycnonotus jocosus

P. cafer

Turdoides striatus

T. affinis

Muscicapa latirostris

Terpsiphone paradisi

Rhipidura aureola

Cisticola juncidis

Prinia hodgsonii

$P$. socialis

Orthotomus sutorius

Acrocephalus dumetorum

Phylloscopus trochiloides

Copsychus saularis

Saxicola caprata

Saxicoloides fulicata

Anthus novaeseelandiae

A. novaeseelandiae malayensis

Motacilla cinerea

M. alba

M. maderaspatensis

Dicaeum erythrorhynchos

D. agile 
Family : Nectariniidae

115. Purple-rumped Sunbird

116. Small Sunbird

117. Loten's Sunbird

118. Purple Sunbird

Family : Ploceidae

119. Yellow-throated Sparrow

120. House Sparrow

121. White-backed Munia

122. Black-headed Munia

123. Spotted Munia

Family : Fringillidae

124. Common Rosefinch

\section{A CASE OF OBSTRUCTIVE ASPHYXIA IN PYTHON (PYTHON MOLURUS)}

\section{P.K.Mehrotra ${ }^{1}$, Sudhir Bhargava ${ }^{2}$, Sheela Chaudhary ${ }^{3}$ and B.B.L.Mathur ${ }^{4}$}

${ }^{1}$ Officer Incharge Associate Professer, ${ }^{2}$ Instructor, ${ }^{3}$ Assistant Professor, Apex Centre, ARS Campus, Durgapura, Jaipur, Rajasthan, India

${ }^{4}$ Veterinary Officer, Zoo, Jaipur, Rajasthan, India

The Apex Centre, Jaipur received a carcass of python in the month of January 1998 from the Zoological Park, Jaipur. With the animal going off-feed during the winter months on account of hibernation, the zoo authorities apparently could not note of the deteriorating health condition of the snake. The general body condition of the carcass was good and the animal measured about 8 feet 6 inch in length. The carcass had no external marks of injury.

All the visceral organs presented white foci of variable size on the exposed surfaces. The gastro-intestinal tract when opened for examination, was found to be totally empty except for the presence of thick mucigenous mass in the posterior part of the intestine. The anterior part of small intestine had numerous round worms attached to the mucosa of the lumen. However, no pathognomonic lesions could be detected in the gastrointestinal tract.

The respiratory tract was explored from mouth to lung through

Received 22 July 1999;

Accepted 3 December 1999 trachea. About 6 inches posterior to mouth the lumen of trachea was found completely occluded with a mass of growth (more than 2 inches long). An incision on the mass revealed the presence of thick pus. Abscesses of variable sizes were found scattered throughout the trachea and in the lung. The lung was found to be totally collapsed. Heart was found empty.

The pus samples along with piece of lung and mucus from intestine were collected for further laboratory investigation. Gram's stained smears of the pus and impression smear of lung revealed the presence of Gram negative non-sporulated rods.

The pus sample was inoculated in blood agar medium. The bacterial growth appearing after incubation at $37^{\circ} \mathrm{C}$ for $24-36$ hours was subjected to purification by subculturing and generic identification tests as per usual microbiological techniques of identification (Carter, 1967). The bacterial isolate recovered from pus sample was identified as Corynibacterium (Actinomyces) pyogenes.

The mucus sample was inoculated in Mac Conkey and S S agar media. The bacterial growth appearing on the media were identified as Esteurichia coli, Proteus sp. and Salmonella sp.

The clinical history, post morten examinations and laboratory investigation were suggestive of obstructive asphyxia as the cause of death in the Python. Rao et al. (1980) reported concomittant occurrence of Corynibacterum pyogenes and Pseudomonas aruginosa in mouth lesions of cobra. Kaura et al. (1972), Sethi et al. (1980a\&b) and, Mishra and Verma (1981) have also reported the presence of enteric bacteria in python and other snakes.

\section{Acknowledgement}

The authors are thankful to Director Research (Veterinary and Animal Science), Rajasthan Agricultural University, Bikaner and Deputy Chief Wildlife Warden, Zoo, Jaipur for providing facilities.

\section{References}

Carter, G.R. (1967). Adv. Vet. Sci. Comp. Med. 11.321.

Kaura, Y.K., V.K. Sharma and I.P. Singh (1972). Snakes as reservoirs of Arizona and Salmonella. Zentrabl. Ba kteriol. 219: 506-13.

Mishra, H.N. and J.C. Verma (1981). Salmonella weltervedan from Cobra. Ind Vet. J. 58: 424

Rao, S.M., S. Zaki., T.S. Nalini and B.S. Keshavamurthy (1980). Concomittant occurrence of Corynibacterium pyogenes and Pseudomonas aruginosa in the mouth lesion of cobras. Curr. Sci. 49: 953.

Sethi, M.S., V.D. Sharma and S.P. Singh (1980a). Reservoirs of Zoonotic diseases of Uttar Pradesh. Technical Report PL 480 Grant No. F. GIN 550, G.B. Pant University and Tehnology, Pant Nagar, Nainital, U.P.

Sethi, M.S., V.D. Sharma and S.P. Singh (1980b). The occurrence of Salmonella in zoo animals in Uttar Pradesh and Delhi (India). Int. J. of Zoon. Dis. 7: 15-18. 